\title{
Benchmarking Non-Performing Loans
}

\author{
Giovanni Cerulli* \\ National Research Council of Italy, Italy \\ Vincenzo D’Apice†\# \\ Italian Banking Association, Italy \\ Franco Fiordelisi \\ Essex Business School, U.K. \\ Francesco Masala§\# \\ Italian Banking Association, Italy
}

\begin{abstract}
This paper provides a new perspective to evaluate the economic role played by banks in nonperforming loans (NPLs) accumulation. We estimate benchmark NPL levels on the judicial inefficiency dimension, controlling for country- and bank-specific factors. To this aim, we first empirically establish whether judicial inefficiency is a key determinant of NPLs in the European banking system for the period 2006-2017. Using the dynamic-Generalized Method of Moments estimations, we show that higher contract enforcement inefficiency increases NPLs. Then, we estimate NPLs benchmark levels using a dose response function based on judicial inefficiency. Our results show that Norway, Sweden, and Italy performed better than the European countries, while Austria, Germany, Spain, Ireland, Cyprus, and Greece performed worse than the European mean. Our results have several policy implications.
\end{abstract}

Keywords: Non-performing loans, European banking Financial stability, Benchmarking JEL classification: E32, G21, G28, C23

\footnotetext{
Acknowledgments: We would like to thank Luisa Carpinelli, Christa Bowman, Ralph de Haas, Radha Gopalan, Iftekhar Hasan, Bill Megginson, David Marques-Ibanez, Bill Megginson, Gordon Phillips, Alexander Plekhanov, Klaus Schaeck, and Anjan Thakor and conference and seminar participants to the American Economic Association 2018, the European Banking Authority 2019, the Financial Intermediation Network of European Studies 2019, Essex University, University of Limoges and CNR-GRAPE for their helpful comments.
} 


\section{Introduction}

Non-performing loans (NPLs) were relatively low and stable across most EU countries until the start of the Great Financial Crises in 2008. Since then, the credit quality of the loan portfolio has declined sharply, and NPLs reached $11.8 \%$ of total loans (i.e., nearly $€ 1$ trillion). The sharp increase in the NPLs reduced bank profitability and increased bank failures (Casu, Girardone, Molyneux, 2015). In some cases (e.g., Spain), the burden of NPLs required government intervention to set up a "bad bank" with the aim of cleaning up bank balance sheets (Jiang, Kanas and Molyneux, 2018; Laeven and Valencia, 2010; Schaeffer and Zimmermann, 2009). Reinhart and Rogoff (2010) argue that NPLs can be used to establish the onset of a banking crisis. Moreover, the deterioration of loans quality hampered the ability of the banking system to supply credit (Tarazi et al., 2018), reducing economic efficiency and activity (Barseghyan, 2010). Thus, understanding the key drivers of NPLs growth is of utmost importance for policymakers, regulators, and bank managers.

There is well-established literature that focuses on the NPLs determinants (see, among others, Berger and DeYoung, 1997; Salas and Saurina, 2002; Louizis et al., 2012; Messai and Jouini, 2013; Makri et al., 2014; Macit, 2012; Cetorelli, 2014; De Nicolò et al., 2019). This literature highlights two different categories of determinants: country-specific factors (e.g., GDP, inflation rate, unemployment, etc.) and bank-specific factors (e.g., profitability, capitalization, loan growth, etc.).

Our paper aims to provide a new perspective in evaluating the economic role played by banks in the NPLs accumulation process. The traditional approach (followed by regulators, practitioners, and academics) focuses on the absolute levels of NPLs to evaluate the responsibility of the banking system. We propose a different approach, based on a new methodology, that focuses 
on the estimation of benchmark NPL levels based on judicial inefficiency and controlling for country- and bank-specific factors. Then, we focus on the gap between actual and benchmark levels of NPLs to assess the role played by the banking system in the NPLs accumulation process of a given country. We estimate benchmark levels using a dose response function, which is innovative in banking literature and fits our research aims. Indeed, to the best of our knowledge, this is the first study that applies dose response function to the NPLs analysis. More precisely, grounded on a regression-adjustment continuous treatment approach, the dose response function partials out other drivers of NPLs by clearly emphasizing the causal impact of judicial inefficiency as if it were a "stand-alone" determinant of NPLs. The response function is found by interpolating a polynomial function whose coefficients are obtained in our main regression model, estimated by the system-Generalized Method of Moments (GMM) (presented in Section 3). The response function uses judicial inefficiency (i.e., number of days needed to enforce a contract in a country) as a dose. Economically, our benchmarks are the NPLs ratio predictions at different levels of judicial inefficiency for an average European bank, accounting for differences in the most important country- and bank-specific factors highlighted by past studies on this topic. As such, the distance between the real country NPLs ratio and the predicted benchmark provide useful insights on domestic banks' responsibility in generating NPLs. We show that banks in Austria, Germany, Spain, Ireland, Cyprus, and Greece performed worse than a mean European bank would have done given the same dose (i.e., the same number of days to enforce a contract). Conversely, banks in Norway, Sweden, and Italy performed better than a mean European bank would have done given the same dose.

Our paper focuses on Europe, since the high level of NPLs has undermined the stability of the banking system. Specifically, we analyze the banks under the ECB banking supervision (i.e., 
single supervisory mechanism banks) and other large European banks. These banks hold almost $82 \%$ of banking assets in the euro area and are located in 21 European countries. Our data cover the period running from 2006 to 2017, strongly characterized by the Global Financial Crisis, the European Sovereign crises, and the severe economic recession that followed in some countries. The analysis of the period could provide relevant policy and practical implications. We base our NPL benchmark analysis on judicial inefficiency, as it is a key determinant of NPLs (as shown in Section 5) but, at the same time, it is also exogenous to the banking system.

The remainder of the paper proceeds as follows: Section 2 reviews the past papers and develops our empirical hypotheses. Section 3 describes our sample, and Section 4 deals with a preliminary investigation. Our empirical analysis is run in two steps: first, we investigate whether judicial inefficiency is a key determinant of NPLs ratio across banks and over several years in Europe (Section 5), and then we estimate a dose response function to benchmark NPL levels with respect to judicial inefficiency (Section 6). Section 7 describes various robustness checks. Finally, Section 8 concludes and outlines the implications of our findings.

\section{Literature review and empirical hypothesis}

Different channels link judicial efficiency to NPL stocks (European Systemic Risk Board, 2019). From a bank's perspective, the legal and judicial system can remarkably influence the persistence of NPL stocks, by settling the contract enforcement and collateral repossession framework (The Council of the EU, 2017). From an investors' perspective, inefficient legal systems discourage investors from buying distressed assets (European Systemic Risk Board, 2017). From a debtor's perspective, the lengthy proceedings can also increase moral hazard, incentivizing strategic default (Schiantarelli, Stacchini and Strahan, 2018). Overall, an inefficient 
foreclosure and restructuring framework is less able to manage the flow of new NPLs and the underlying inertia will have a more lasting impact on the stock. Moreover, long credit recovery procedures affect recovery rates, thus reducing the market value of NPLs, constraining their disposal and, therefore, contributing to a systemic build-up of NPLs. Therefore, a legal and judicial system supporting efficient and effective insolvency proceedings can have a significant impact on the quality of bank assets (EBA, 2016; Carpinelli et al., 2016; Jassaud and Kang, 2015). Thus, our main hypothesis is that higher contract enforcement inefficiency leads to an increase in the NPL ratio (judicial inefficiency hypothesis).

Notwithstanding the increasing attention to the main determinants of non-performing loans, the empirical evidence on these channels is relatively scarce. For example, Jappelli, Pagano and Bianco (2005) study the effect of judicial efficiency on the availability and cost of credit both theoretically and empirically. Their model suggests that improvements in judicial efficiency reduce credit constraints and increase the volume of lending. They test these predictions using a panel data from Italian provinces. Using a fixed effects estimator, they find that lower judicial efficiency is associated with lower volume of credit and higher default rate. More recently, Schiantarelli, Stacchini and Strahan (2018) analyze the empirical frequency with which borrowers delay repayment to their lenders. Using information on bank loans to firms in Italy, they find that borrowers' tendency to delay payments to distressed banks only occurs in parts of Italy where legal enforcement is poorer. Based on this result, they suggest that reforming the judicial processes for recovering collateral offers the potential of improving banks' balance sheets and enhancing financial stability.

Our paper is different in several ways. First, our analysis uses bank-level data. Second, we provide a benchmark analysis. Third, our benchmark analysis is based on a GMM estimator that 
is more suited to capture the dynamic properties of the dependent variable. Fourth, our sample includes 124 banks from 21 European countries. Unfortunately, our data do not allow to test at European level the "strategic default" hypothesis proposed by Schiantarelli, Stacchini and Strahan (2018). This could be an avenue for future research.

More in general, the empirical literature that investigates the possible determinants of NPLs is large. Salas and Saurina (2002), when examining Spanish commercial and savings banks, find that the GDP growth rate, business and family indebtedness, rapid past credit or branch expansion, inefficiency, portfolio composition, size, net interest margin, capital ratio, and market power are the variables explaining credit risk. Similarly, Louizis et al. (2012) show that NPLs are mainly influenced by macroeconomic variables in Greek commercial banking. Focusing on Italy, Greece, and Spain between 2004 and 2008, Messai and Jouini (2013) show that both economic growth and bank profitability reduce NPLs while unemployment rates, real interest rates, and poor credit standards positively influence NPLs. Makri et al. (2014) investigate the factors affecting the NPLs of the Eurozone's banking systems in the period 2000-2008 (just before the beginning of the Great Recession) and find strong correlations between NPLs and various macroeconomic variables (i.e., public debt, unemployment, and GDP growth rate) as well as bank-specific factors (capital adequacy ratio, rate of NPLs in the previous year, and ROE). Macit (2012) studies the determinants of the NPL ratio for commercial banks in Turkey and finds that banks with a higher ratio of equity to total assets and a higher net interest margin are likely to exhibit a higher NPL ratio, whereas an increase in the net loans to total assets ratio is likely to reduce NPLs. However, none of these studies considers the contract efficiency as possible determinants of NPLs.

\section{Data}


To have a wide representation of the European banking industry, we initially collected data for 140 banking groups (henceforth banks): 128 banks included in the preliminary list of the European Central Bank Comprehensive Assessment (list released by the ECB in July 2014) plus 12 other large banks located in the UK, Denmark, Sweden, and Norway. In the second stage, we excluded banks not reporting complete balance sheet data and those with a ratio between loans to customers and total assets lower than $10 \%$. Our final sample consists of 124 banks under the single supervisory mechanism (SSM) and other large European banks located in 21 European countries. ${ }^{1}$ Our dataset is a balanced panel with 1,191 observations spanning the period from 2006 to 2017 . Table 1 shows definition, source, and summary statistics of the variables used in the empirical analysis.

\section{$<$ Insert Table 1>}

We define the NPL ratio as total impaired loans over total gross loans to customers ${ }^{2}$. The denominator of this ratio includes mortgage loans, other retail loans, corporate and commercial loans, other loans, and reserves for impaired loans ${ }^{3}$. The numerator represents the impaired loans included in gross loans to customers. ${ }^{4}$ In our sample, this ratio (NPL ratio) has a mean of $8.4 \%$ and a standard deviation of $10 \%$.

Looking at NPLs in different countries (Table 2), we find the highest NPL ratio, on average over the period of study, in Greece (23.2\%), Slovenia (20.7), and Cyprus (18.7\%). On the contrary,

\footnotetext{
${ }^{1}$ Austria, Belgium, Cyprus, Denmark, Estonia, Finland, France, Germany, Greece, Ireland, Italy, Latvia, Malta, Netherlands, Norway, Portugal, Slovakia, Slovenia, Spain, Sweden, United Kingdom.

${ }^{2}$ For a cross-country comparison, NPLs by category (e.g., mortgage, business, and consumer loans) are not available on Bankscope.

${ }^{3}$ In the denominator, we include the reserves for impaired loans as the other items are net figures.

${ }^{4}$ As highlighted by Nir (2013), "Bankscope reports the level of impaired loans, which may be different to the official classification of non-performing loans. Impaired loans is an accounting concept, which reflects cases in which it is probable that the creditor will not be able to collect the full amount specified in the loan agreement, while 'NPLs is a regulatory concept, which primarily reflects loans that are more than 90 days past due'. That said, we treat impaired loans as NPLs in our study.
} 
Sweden (1\%), Norway (1.7\%), and Estonia (2.8\%) recorded the lowest level of NPL ratio. The mean levels of NPL ratios in our sample (at 2016) are highly consistent with those published in the EBA (2016) report on NPLs in Europe.

\section{$<$ Insert Table 2>}

Our main test variable is the judicial inefficiency, which is equal to the days required to enforce contracts. This index, provided by the World $\mathrm{Bank}^{5}$, measures the time necessary to resolve a dispute from the moment the plaintiff files the lawsuit in court until payment. It includes both the days when actions take place and the waiting periods in between. In our sample, the mean number of days needed to enforce a contract is 595 , with a standard deviation of 302 . We find high levels of judicial inefficiency in Slovenia (1,285 days), Italy (1,203 days), and Greece (1135 days). On the contrary, Norway (300 days), Finland (338 days), and Latvia (371) reported low levels of judicial inefficiency.

As control variables, we use systematic as well as idiosyncratic factors. Regarding systematic factors, we employ two variables: economic activities and interest rates. To measure a country's economic activity, we use the real GDP growth rate. In our sample, the mean value of this variable is $0.6 \%$, with a standard deviation of $3.1 \%{ }^{6}$. Our measure of interest rates is the interest rates on 10-year benchmark government bonds for several reasons. First, the sovereign debt crisis and the emergence of financial fragmentation within the Eurozone showed that, over the period we analyzed, the most important factor influencing the cost of borrowing for banks was sovereign risk. Second, this type of interest rates is available and comparable to all the countries in our database. Third, the correlation between the benchmark rate and the lending rate to the

\footnotetext{
${ }_{6}^{5}$ http://www.doingbusiness.org/en/data/exploretopics/enforcing-contracts

${ }^{6}$ Since some banks in the sample operate in different countries, as a robustness check we use the real GDP growth weighted of the relative share of loans in each country. As it can be seen in Section 6, the results are unchanged.
} 
private sector is usually high $^{7}$. In our dataset, the mean value of this variable is $3.2 \%$, with a standard deviation of $2.6 \%$.

Focusing on idiosyncratic factors, we include the following three variables: bank capitalization, profitability, and credit growth. We proxy bank capitalization using the ratio of Tier 1 regulatory capital to risk weighted assets; in our sample, the mean value of this variable is $11.7 \%$, with a standard deviation of 2.9. We measure profitability using return on assets; in our sample, the mean value of this variable is $0 \%$, with a standard deviation of $1.6 \%$. We calculate credit growth as the yearly growth rate of loans; the mean value of this variable is $0 \%$, with a standard deviation of $5.3 \%$.

\section{Preliminary investigation}

We report some charts that enable us to gain some preliminary insight into the NPL accumulation process in Europe. Figure 1 reports the NPL ratio trend over time. NPLs across European countries were relatively low and stable until the outbreak of the Global Financial Crisis (see Panel A). Indeed, in the first three years, the mean value of the NPL ratio was around $2.7 \%$, and the standard deviation was even lower and slightly declining. Since 2009 , the credit quality of loan portfolios deteriorated sharply, with the increase in financial instability and the slowdown of real economy. As a matter of fact, the mean value of NPL ratio skyrocketed from $2.7 \%$ to $11.8 \%$ in 2014 . At the same time, the volatility of NPLs across banks increased; the coefficient of variation increased from $83 \%$ to $112 \%$ of the mean. In addition to the increase in the ex-post lending risk, we are interested in explaining the increase in the dispersion across banks and over time. Thus, in Panel B of Figure 1, we show the trend in the $25^{\text {th }}, 50^{\text {th }}$, and $75^{\text {th }}$ percentiles of the NPL ratio's distribution

\footnotetext{
${ }^{7}$ For example, in Germany is 0.98 , in France 0.96, in Spain 0.70.
} 
over time. As can been seen, up to 2008, the distance between these three groups of banks was fairly constant. Since 2009 , there is a divergence in the distribution of NPLs, which is due to a considerable increase in loan risk in the $75^{\text {th }}$ percentile of banks. This suggests that, since 2009, the mean NPL ratio of one-quarter of the banks has increased far more than other banks.

$<$ Insert Figure 1>

Table 3 reports the correlation matrix of our variables. As expected, NPLs are negatively correlated with GDP growth and bank profitability, while they are positively related to sovereign bond yield and judicial inefficiency. Overall, the correlation among the explanatory variable is low.

\section{$<$ Insert Table 3>}

Table 4 shows the stationarity test of the variables used in the multivariate analysis. Specifically, we perform the Levin et al. (2002) and the Im et al. (2003) panel unit root tests that assume a common unit root process. We also provide the results of the Fisher-ADF tests that assume individual unit root processes. We can reject the null hypothesis (non-stationarity) for all variables used.

$<$ Insert Table 4>

\section{The effect of judicial inefficiency on non-performing loans}

Our empirical analysis is run in two steps. First, we test whether judicial inefficiency is a key determinant of the NPL ratio across banks and over the years in Europe, and second, we estimate a dose response function to benchmark NPL levels based on judicial inefficiency. 
In the first step, we estimate the link between NPL levels and judicial inefficiency controlling for the most important macro- and micro-economic factors. To this end, we employ, in various forms, the following dynamic panel model:

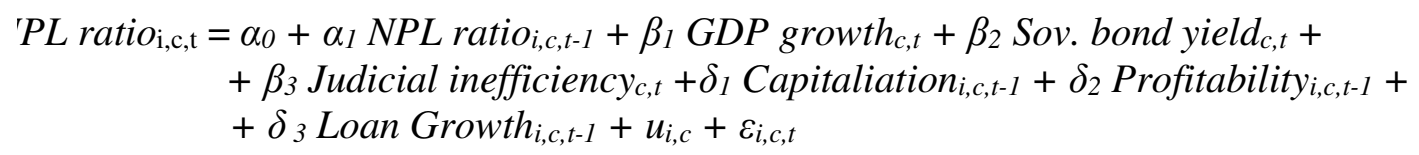

$$
\left|\alpha_{1}\right|<1 ; i=1 \ldots \mathrm{N} ; c=1 \ldots \mathrm{M} ; t=1 \ldots \mathrm{T}
$$

where $N P L$ ratio $_{\mathrm{i}, \mathrm{c}, \mathrm{t}}$ denotes the ratio of non-performing loans ${ }^{8}$ over total loans for bank $i$, located in country $c$, at time $t$. Following past papers (Ghosh, 2015; Nir, 2013), we express our dependent variable as the logit transformation of the NPL ratio ${ }^{9}$. As systematic factors (i.e., country specific), we use three explanatory variables: GDP growth $_{c, t}$ denotes the annual growth rate of the country's real economic activity, Sov. Bond yield $c_{c, t}$ is the yearly mean of interest rate for the country's 10year government bonds, Judicial inefficiency $y_{c, t}$ is the number of days needed to enforce contracts in a country. As idiosyncratic factor (i.e., bank-specific), we use three variables as a one-year lag to reduce possible endogeneity problems: capitalization $_{i, c, t-l}$ denotes the ratio of Tier 1 regulatory capital to total asset, Profitability $i_{i, c, t-1}$ is the return on assets, and Loan Growthi,c,t-1 is the annual bank's loan growth rate. The term $u_{i, c}$ represents the bank fixed effects and the term $\varepsilon_{i, c, t}$ is an independent and identically distributed error term. We use the two-step system-GMM estimator with a Windmeijer (2005) corrected standard error to conduct our analysis (Arellano and Bover, 1995; Blundell and Bond, 1998; Roodman, 2009). ${ }^{10}$

\section{$<$ Insert Table 5>}

\footnotetext{
${ }^{8}$ That is, loans past due $>90$ days.

${ }^{9}$ More precisely: $\mathrm{npl}_{\mathrm{i}, \mathrm{c}, \mathrm{t}}=\ln \left[\mathrm{npl}_{\mathrm{i}, \mathrm{c}, \mathrm{t}}\left(1-\mathrm{npl}_{\mathrm{i}, \mathrm{c}, \mathrm{t}}\right)\right]$.

10 The estimated asymptotic standard errors of the efficient two-step GMM estimator are severely downward biased in small samples, thus we correct this bias using the method proposed by Windmeijer (2005).
} 
Table 5 shows the results ${ }^{11}$. The estimated coefficient on judicial inefficiency is highly significant in all models, meaning that contract enforcement is important for NPLs. The positive sign on this coefficient supports our "judicial inefficiency hypothesis": the higher number of days required to enforce contracts increases the NPL ratio. Indeed, lengthy foreclosure process implies that the disposal of NPL stocks will take a longer time, thus contributing to a build-up of NPLs. Moreover, in a such context, the new NPLs management is less efficient and the underlying inertia will have a more lasting impact on the stock.

Regarding country specific controls, the coefficient on the GDP growth is highly significant in all models, suggesting a strong influence of business cycles on the ex-post loan portfolio risk. The coefficient on the sovereign bond yield is highly significant in all models, which indicates that the interest rate on public debt influences the credit quality of the banking system. Concerning bankspecific controls, the estimated coefficient on loan growth is barely significant, providing a weak evidence of correlation between aggressive commercial policy and ex-post loan portfolio risk. The coefficients on capitalization and profitability are not statistically significantly different from zero. We also consider possible differences due to types of loans (Louzis et al., 2012) and geographic distribution of loans. As can be seen in the Appendix, the strong influence of judicial efficiency on NPL ratio is confirmed.

In line with the literature on this topic, our results show that macroeconomic factors such as GDP and interest rates are key drivers of NPLs. Importantly, we add new insights to this literature showing the important role played by judicial efficiency. In the next section we analyze this role with a dose response function.

\footnotetext{
${ }^{11}$ The estimation procedure uses 167 instruments. More precisely, it uses lags from three to five as instruments for first differences equation; while it uses the first difference of lag two as instruments for levels equation.
} 


\section{Benchmarking Non-Performing Loans levels}

In this section, we use our base model to estimate a dose response function. In Section 6.1 we explain the methodology while in Section 6.2 we show the results.

\subsection{Dose response function: methodology}

We now shift our focus onto the economic role played by banks in the NPLs accumulation process. The traditional approach followed by regulators, practitioners, and academics, focuses on the absolute levels of NPLs to evaluate the responsibility of the banks. We propose a different approach based on a dose response function. More precisely, we estimate a benchmark NPL level based on judicial inefficiency, controlling for the most important country- and bank-specific factors highlighted by past studies and by our empirical analysis. We use the judicial inefficiency as it is a key determinant of NPLs, but, at the same time, it is also exogenous to the banking system. Focusing on the gap between actual and benchmarking levels of NPLs, we can assess the role played by the banking system in the NPL accumulation process of a given country.

Using a dose response function, we estimate the benchmark level of NPLs ratio. This methodology is innovative in banking and it fits our research aims. Grounded on a regressionadjustment continuous treatment approach, the dose response function partials out other drivers of NPLs by clearly emphasizing the causal impact of a systemic factor (i.e., judicial inefficiency) as if it was a "stand-alone" determinant of NPLs. Generally neglected in standard regression analysis, this stand-alone focus exhibits two important advantages. First, it allows for an estimation of a benchmark pattern identified by the average (i.e., country common component) pattern of the relation between NPLs and the specific systemic factor. Second, it provides an easy-to-read 
graphical representation of the results, clearly positioning each country with respect to the benchmark estimation. This makes results more readable, fair, and self-evident.

We estimate the response function by interpolating a polynomial function whose coefficients are obtained in a regression estimated by system-GMM presented in Section 3. Therefore, we are able to set out the pattern of NPLs (and provide confidence intervals) over different levels of judicial inefficiency, controlling for other economic factors at the country- and bank-levels.

Specifically, we use a panel data regression estimating the following equation:

$Y_{i t}=\alpha+\beta Y_{i, t-1}+\sum_{j} \gamma_{j} M A_{j}+\sum_{j} \delta_{j} M I_{j}+h\left(s_{i, t-1}\right)+A_{i}+B_{t}+\varepsilon_{i, t}$

where $Y$ is the NPL ratio at time $t$ for bank $i$; MA are the country-specific variables (namely, GDP growth, sovereign bond yield, and judicial inefficiency); $M I$ are the bank-specific variables (specifically, capitalization, profitability, and loan growth). We also include bank $\left(A_{i}\right)$ and year $\left(B_{t}\right)$ fixed effects. More importantly, we are interested in estimating $h(s)$; it represents the NPLs response function to any specific systemic factor $s$ by taking all the other NPLs determinants as given. In order to justify an estimation of $h(s)$, we derive Eq. (1) from a "continuous treatment" model of this type (see Cerulli, 2015):

$$
\mathrm{E}(y \mid \mathbf{x}, w, s)=\mu_{0}+\mathbf{x} \boldsymbol{\delta}_{0}+w \underbrace{w\left[\left(\mu_{1}-\mu_{0}\right)+\overline{\mathbf{x}}\left(\boldsymbol{\delta}_{1}-\boldsymbol{\delta}_{0}\right)+\bar{h}\right]}_{\text {ATE }}+w[\mathbf{x}-\overline{\mathbf{x}}]\left(\boldsymbol{\delta}_{1}-\boldsymbol{\delta}_{0}\right)+w[h(s)-\bar{h}]
$$

where $\mathbf{x}$ are covariates, $w$ the treatment 0/1 dummy, and $h(s)$ the outcome-response function to the dose $s$. If $w=1$, i.e., when all individuals are treated as in our sample, the previous equation simplifies to:

$$
\mathrm{E}(y \mid \mathbf{x}, w, s)=\mu_{1}+\boldsymbol{\delta}_{1} \mathbf{x}+h(s)
$$

that is a concise representation of Eq. (1), when one assumes $\mathbf{x}$ to contain the lagged $y$, the micro 
and macro variables, and the fixed effects. As in Eq. (1), our main objective is to estimate the response function $h(s)$. In order to do this, we give $h(s)$ a $q$-degree polynomial specification:

$$
h(s)=\alpha_{1} s+\alpha_{2} s^{2}+\alpha_{3} s^{3}+\ldots+\alpha_{q} s^{q}
$$

Once plugged-in into Eq. (3), we estimate Eq. (4) through a consistent procedure: in our case a system-GMM. With this estimation at hand, we obtain the outcome-response function $H(s)$ by averaging over $\mathbf{x}$ :

$$
H(s)=\mathrm{E}_{\mathbf{x}} \mathrm{E}(y \mid \mathbf{x}, s)=\mu_{1}+\boldsymbol{\delta}_{1} \overline{\mathbf{x}}+\alpha_{1} s+\alpha_{2} s^{2}+\alpha_{3} s^{3}+\ldots+\alpha_{q} s^{q}
$$

The function $H(s)$ is at the heart of our estimation purposes. Indeed, if a consistent and asymptotically normal estimation of $H(s)$ is available, its estimated variance would take on this form:

$$
\hat{\sigma}_{\hat{H}(s)}=\left\{S_{1} \hat{\sigma}_{\hat{\alpha}_{1}}^{2}+S_{2} \hat{\sigma}_{\hat{\alpha}_{2}}^{2}+S_{3} \hat{\sigma}_{\hat{\alpha}_{3}}^{2}+2 S_{1} S_{2} \hat{\sigma}_{\hat{\alpha}_{1}, \hat{\alpha}_{2}}+2 S_{1} S_{3} \hat{\sigma}_{\hat{\alpha}_{1}, \hat{\alpha}_{3}}+2 S_{2} S_{3} \hat{\sigma}_{\hat{\alpha}_{2}, \hat{\alpha}_{3}}+\ldots\right\}^{1 / 2}
$$

where $S_{1}=s, S_{2}=s^{2}, S_{3}=s^{3}, \ldots$ As a consequence, the (1- $\left.\alpha\right) \%$ normal-based confidence interval for $\hat{H}(s)$ at each $s$ is given by:

$$
\left\{\hat{H}(s) \pm z_{1-\alpha} \cdot \hat{\sigma}_{\hat{H}(s)}\right\}
$$

Once estimated by system-GMM, we can plot the response curve $H(s)$ along with its confidence intervals.

\subsection{Dose response function: results}

We focus on judicial inefficiency showing the results of system-GMM estimation of the response function $H(s)$ described in the previous section. Here the dose is the number of days needed to enforce a contract, and the response is the NPL ratio. Specifically, we standardize judicial inefficiency to range between 0 and 100 (with zero meaning the maximum efficiency of the judicial 
system. and a hundred meaning the maximum inefficiency). Figure 2 shows a highly significant and increasing pattern of the NPLs ratio as a function of the dose, with a positive polynomial second order term (Panel A). As an estimate of Eq. (5), this pattern shows the NPL ratio predictions (and 95\% confidence intervals) over different levels of judicial inefficiency, partialled-out with regards to the other systematic and idiosyncratic variables reported in Eq. (1). Economically, this pattern is the NPLs ratio predictions at different levels of judicial inefficiency for an average European bank, once accounting for differences in micro and macro conditions. It can be used to identify a benchmark for a real NPLs ratio, with the distance between a real country NPLs ratio and the predicted benchmark showing domestic banking system responsibility in generating NPLs.

< Insert Figure 2>

We find that banks in Latvia, Austria, Germany, Spain, Ireland, Cyprus, and Greece performed worse than a mean European bank would have performed given the same dose (i.e., the same number of days to enforce a contract), as their levels of NPLs ratio are above the $95 \%$ confidence interval (see Panel A and Panel B for a better identification of the countries with judicial inefficiency between zero and thirty). Conversely, banks in Norway, Sweden, and Italy performed better than a mean European bank would have performed, given the same dose, as their levels of NPLs ratio are below the 95\% confidence interval. Despite great heterogeneity of observations, the goodness-of-fit for judicial inefficiency is satisfactory (Panel C). This panel jointly plots the distribution of NPLs actual values and those predicted by the model. The results demonstrate that they overlap rather well.

Overall, our results show that in the countries performing better than the European mean, the banking system was a positive factor. For example, in the case of Italy, with a standardized measure of judicial inefficiency near 90, the level of the NPLs ratio should have been higher than 
$20 \%$. However, the actual value has been near $12 \%$, and this difference is statistically significant. On the contrary, in the countries performing worse than the European mean, the banking system was a negative factor. For example, in the case of Ireland, with a standardized measure of judicial inefficiency near $27 \%$, the level of the NPLs ratio should have been near to $5 \%$. However, the actual value has been $20 \%$, and this difference is statistically significant.

\section{Robustness checks}

In this section, we provide various robustness tests. Initially, to mitigate the potential omittedvariable bias, we add to the complete specification of our model a broad set of dummies as additional control variables (Table 6, Panel A). First, we define three dummies for bank size: (i) small banks with total assets lower than $€ 10$ billion, (ii) medium banks with total assets between $€ 10$ billion and $€ 50$ billion, and (iii) large banks with total assets higher than $€ 50$ billion. We find that bank size does not add explanatory power to our preferred specification (Model 2.1). Second, we also add three dummies for bank specialization: (i) commercial banks, (ii) investment banks, and (iii) other banks. These dummies are not significant (Model 2.2). Third, we also account for systemic risk by adding a dummy equal to 1 if a bank is classified as a systemically important financial institution (SIFI) and zero otherwise. As can be seen from Model 2.3, this dummy variable is not significantly related to bank credit quality.

$$
<\text { Insert Table 6> }
$$

As the next step, we verify whether different bank-specific variables could alter the results. Specifically, we use different variables for bank capitalization (total equity capital ratio in lieu of the Tier 1 regulatory capital ratio) and bank profitability (ROE instead of ROA) in our base model. As can be seen in Table 6 Panel B (Models 2.4 and 2.5 respectively), these bank-specific variables 
do not demonstrate explanatory power regarding the NPL ratio, once we control for country- and bank-specific variables.

Many banks in our sample operate in different countries. Thus, as an additional check for each bank, we use the real GDP growth weighted for the relative share of loans in each country. We calculate this variable using the quantities provided by the European Banking Authority for 2013. As can be seen in Table 6 (Model 2.6), using this variable, in lieu of unweighted GDP growth, produces very similar results.

Moreover, we include the unemployment rate in the base model with country-specific variables only. As can be seen in Table 6 (Model 2.7), this variable is not statistically significant. As discussed above, we estimated Eq. (1) using the system-GMM estimator. For our final robustness tests, we re-estimate our model using a fixed effects estimator. Results are displayed in Table 6, Panel B, Model 2.8. The coefficient on the judicial inefficiency exhibits the same signs and explanatory power, with even higher magnitude ${ }^{12}$.

\section{Conclusions}

Non-performing loans became a first-order problem in the aftermath of the recent crisis. The deterioration of loans quality hampers the ability of the banking system to supply credit. This, in turn, creates financial stability issues and reduced economic activity. Several empirical works studied the causes of NPLs. We contribute to this stream of literature providing a NPLs benchmark analysis based on judicial inefficiency. To this end, we first empirically examine whether judicial inefficiency is a key determinant of non-performing loans in the European banking system for the period 2006-2017. Using dynamic-GMM estimations and controlling for systematic and

\footnotetext{
${ }^{12}$ Simple OLS estimation provides similar conclusions. Results are available upon request.
} 
idiosyncratic factors, we find that higher contract enforcement inefficiency increases NPLs. Moreover, we also confirm that GDP growth and interest rates influence NPLs.

Then, we estimate a NPLs benchmark level to identify the banking systems that performed better and worse than the European mean. We base our NPL benchmark analysis on judicial inefficiency as it is a key determinant of NPLs; however, at the same time, it is also exogenous to the banking system. We show that banks in Austria, Germany, Spain, Ireland, Cyprus, and Greece performed worse than a mean European bank while banks in Norway, Sweden, and Italy performed better than a mean European bank.

From a policy perspective, our results endorse a macro-prudential approach to financial stability. Structural reforms supporting judicial efficiency, economic growth, and fiscal discipline are critical to strengthen banking sector stability. The guarantee on the securitization of NPLs (e.g. the GAGS instruments introduced in Italy in 2016) can facilitate the removal of non-performing loans from the banking book of commercial banks. However, in addition to these types of policy interventions, we show that improvements in the efficiency of the judicial system would have significant positive effects on the banking sector. Our results show that reforms aimed at reducing the time needed to enforce a contract are a useful tool to deal with the NPLs overhangs. 


\section{References}

Arellano, M., Bover, O., 1995. Another look at the instrumental-variable estimation of errorcomponents. Journal of Econometrics 68, 29-52.

Barseghyan, L., 2010. Non-performing loans, prospective bailouts, and Japan's slow-down. Journal of Monetary Economics 57, 873-890.

Berger, A., DeYoung, R., 1997. Problem loans and cost efficiency in commercial banks. Journal of Banking and Finance 21, 849-870.

Blundell, R., Bond, S., 1998. Initial conditions and moment restrictions in dynamic panel data models. Journal of Econometrics 87, 115-143.

Carpinelli, L., Cascarino, G., Giacomelli, S., Vacca, V.P., 2016. The management on nonperforming loans: a survey among the main Italian banks", Occasional Paper, No 311, bank of Italy.

Casu, B., Girardone, C., Molyneux, P., 2015. Introduction to Banking, 2nd edition. Pearson, U.K.

Cerulli, G., 2015. CTREATREG: Stata module for estimating dose-response models under exogenous and endogenous treatment, The Stata Journal 15, 1019-1045.

Cetorelli, N., 2014. Banking and Real Economic Activity, in The Oxford Handbook of Banking, 2nd Edition, Allen N. Berger, Phillip Molyneux and John Wilson, Eds., Series, Oxford Handbooks in Finance, Oxford University Press.

Council of the EU, 2017. Report of the FSC Subgroup on Non-Performing Loans.

De Nicolò, G., Boyd, J.H., Rodionova, T., 2019. Banking crises and crisis dating: Disentangling shocks and policy responses. Journal of Financial Stability 41, 45-54 
European Banking Authority, 2016. EBA report on the dynamics and drivers of non-performing exposures in the EU banking sector.

European Banking Authority, Transparency Exercise 2015-2019.

European Banking Authority, EU-wide stress testing, 2014, 2016, and 2018.

European Systemic Risk Board, 2017. Resolving non-performing loans in Europe.

European Systemic Risk Board, 2019. Macroprudential approaches to non-performing loans.

Ghosh, A., 2015. Banking-industry specific and regional economic determinants of nonperforming loans: Evidence from US states. Journal of Financial Stability 20, 93-104.

Im, K.S., Pesaran, M.H., Shin, Y., 2003. Testing for unit roots in heterogeneous panels. Journal of Econometrics 115, 53-74.

International Monetary Fund, World Economic Outlook Database.

Jappelli T., Pagano M., Bianco M., 2005. Courts and banks: effects of judicial enforcement on credit markets. Journal of Money, Credit and Banking, 37, 223-244.

Jassaud, N., Kang, K., 2015. A strategy for developing a market for nonperforming loans in Italy. IMF WP/15/24.

Jiang C., Kanas A., Molyneux P., 2018. Public policy and financial stability: The impact of PCA and TARP on US bank non-performing loans. International Journal of Finance \& Economics, Volume23, Issue4: 376-392.

Laeven, L., Valencia, F., 2010. Resolution of Banking Crises: The Good, the Bad, and the Ugly, IMF working paper 10/146.

Levin, A., Lin, C., Chu, C.J., 2002. Unit root tests in panel data: Asymptotic and finite sample properties. Journal of Econometrics 108, 1-24. 
Louizis, D., Vouldis, A., Metaxas, V., 2012. Macroeconomic and bank-specific determinants on non-performing loans in Greece: A comparative study of mortgage, business and consumer loan portfolios. Journal of Banking and Finance 36, 1012-1027.

Macit, F., 2012. What determines the non-performing loans ratio: evidence from Turkish commercial banks. CEA Journal of Economics 13, 33-39.

Makri, V., Tsagkanos, A., Bellas, A., 2014. Determinants of non-performing loans: The case of eurozone. Panoeconomicus 2, 193-206.

Messai, A., Jouini, F., 2013. Micro and macro determinants of non-performing loans. International Journal of Economics and Financial Issues 3, 852-860.

Nir, K., 2013. Non-performing loans in CESEE: Determinants and impact on macroeconomic performance. IMF WP/13/72.

Reinhart, C., Rogoff, K., 2010. From Financial Crash to Debt Crisis. NBER Working Paper 15795.

Roodman, D., 2009. How to do xtabond2: An introduction to "difference" and "system" GMM in Stata. Stata Journal 9, 86-136.

Salas, V., Saurina, J., 2002. Credit risk in two institutional regimes: Spanish commercial and savings banks. Journal of Financial Services and Research 22, 203-224.

Schaeffer, D., Zimmermann, K.F., 2009. Bad bank(s) and the recapitalization of the banking sector. Intereconomics: 44: :215-225.

Schiantarelli F., Stacchini M., Strahan P.E., 2018. Bank quality, judicial efficiency and borrower runs: Loan repayment delays in Italy. Journal of Finance, forthcoming. 
Tarazi, A., Soedarmono, W., Agusman A., Monroe, G.S., Gasbarro, D., 2018. Loan Loss Provisions and Bank Lending Behavior: Do Information Sharing, Strength of Legal Rights and Bank Size Matter? Available at SSRN: https://ssrn.com/abstract=2782707

Windmeijer, F., 2005. A Finite Sample Correction for the Variance of Linear Efficient Two Step GMM Estimators. Journal of Econometrics 126, 25-51.

World Bank, Doing Business Database. 


\section{Figure 1-NPLs Trend}

Figure 1 includes two Panels. In Panel A, we plot the mean level and standard deviation of the NPL ratio between 2006 and 2017. In Panel B, we report the trend in the $25^{\text {th }}, 50^{\text {th }}$, and $75^{\text {th }}$ percentiles of the NPL ratio's distribution over time.

$\underline{\text { Panel A }}$

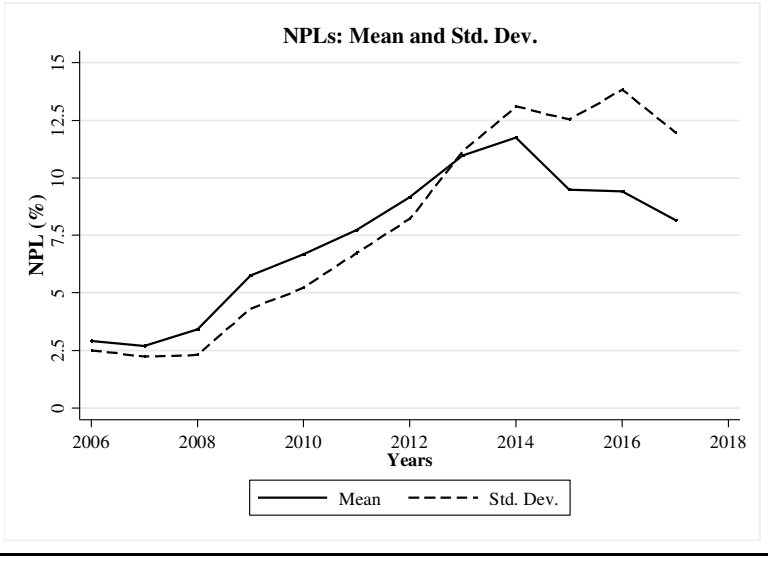

$\underline{\text { Panel B }}$

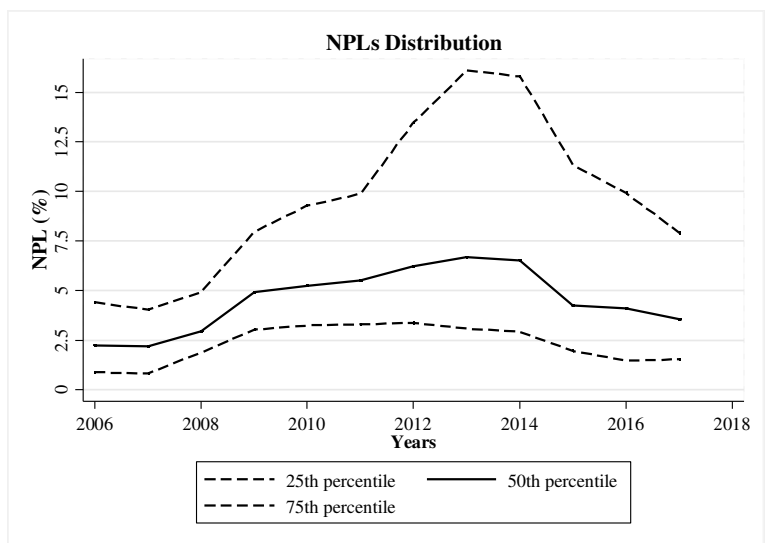




\section{Figure 2-The effect of judicial inefficiency on NPLs}

Figure 2 shows system-GMM estimation of the response function $H(s)$ as described in Section 6.1. This is the pattern of NPL ratio predictions over different levels of judicial inefficiency. We standardize judicial inefficiency to range between 0 and 100 . We obtain our results by adapting a continuous treatment approach to our context, as set out in Section 6.1. We plot $95 \%$ confidence intervals curves for $H(s)$ at any level of judicial inefficiency. A polynomial function interpolates the response function with coefficients obtained through system-GMM. A second order polynomial curve provides the best fit. All variables are defined in Table 1.

\section{Panel A-Dose response function reporting mean country-level data-all sample}

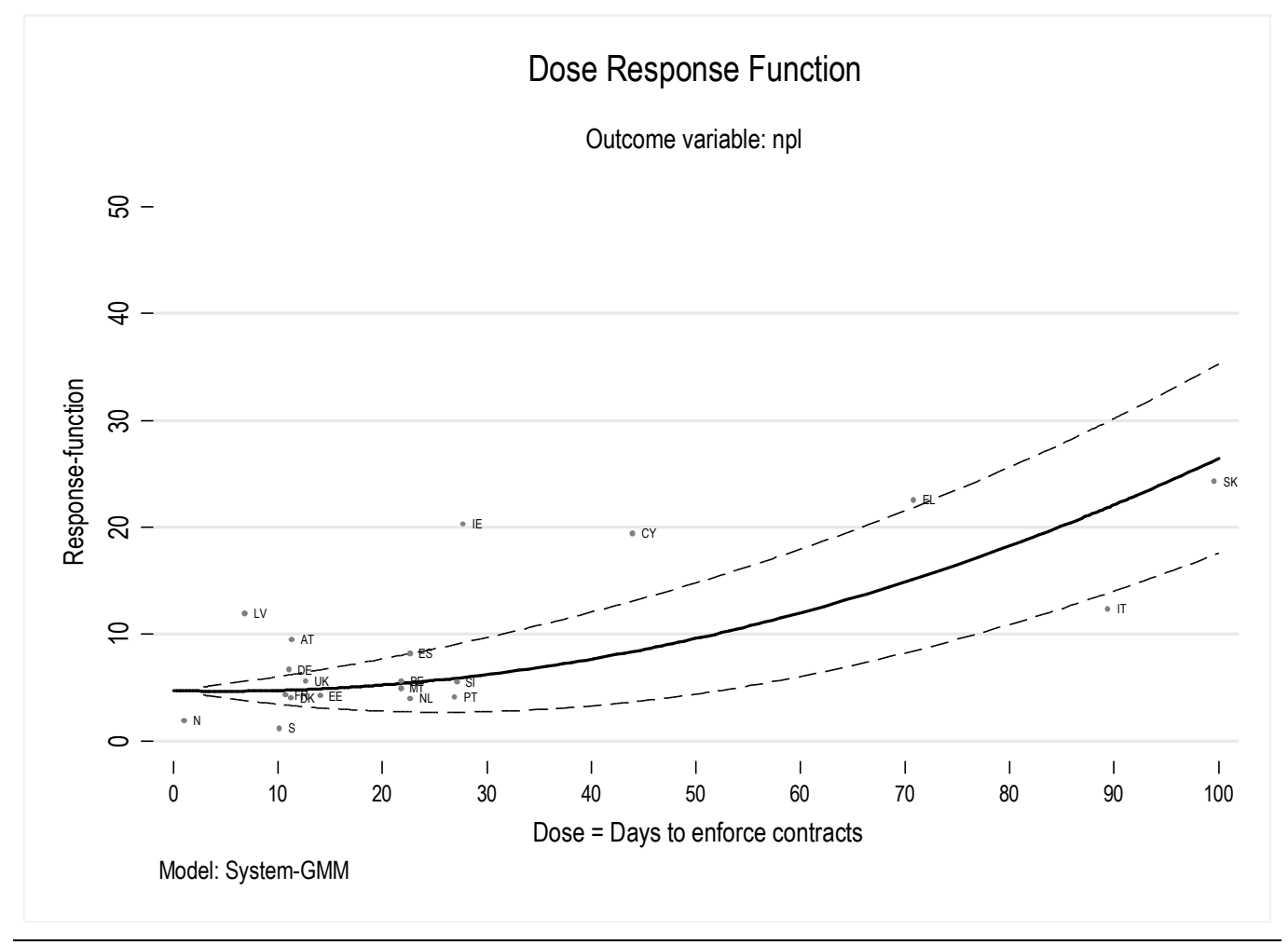

$\mathrm{AT}=$ Austria, BE=Belgium, $\mathrm{CY}=$ Cyprus, DK=Denmark, EE=Estonia, FI=Finland, FR=France, DE=Germany,

$\mathrm{EL}=$ Greece, $\mathrm{IE}=$ Ireland, IT=Italy, LV=Latvia, MT=Malta, NL=Netherlands, N=Norway, PT=Portugal, SI=Slovakia, $\mathrm{SK}=$ Slovenia, $\mathrm{S}=$ Sweden, $\mathrm{ES}=$ Spain, $\mathrm{UK}=$ United Kingdom

Panel B-Dose response function reporting mean country-level data-subsample of countries with judicial inefficiency between 0 and 30. 


\section{Dose Response Function}

Outcome variable: npl

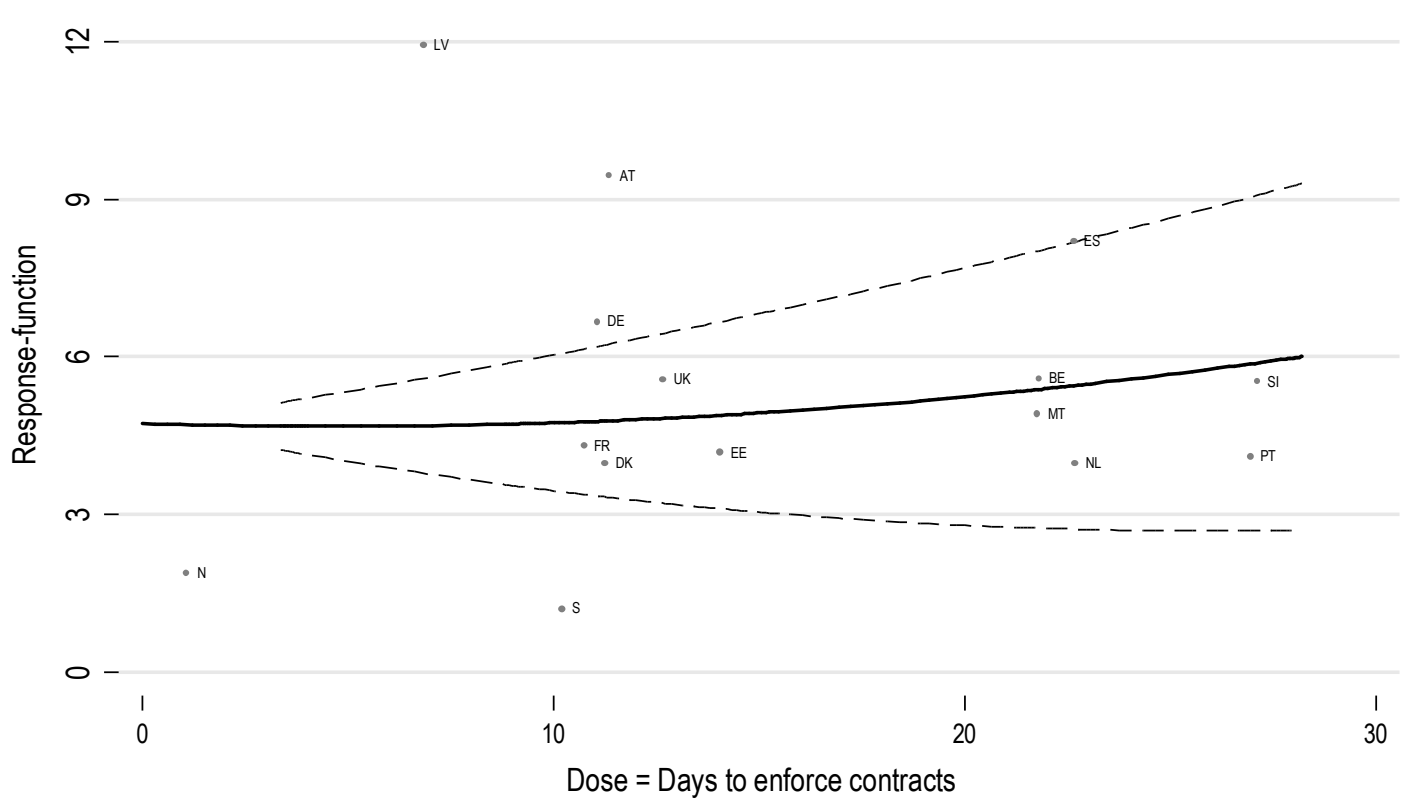

Model: System-GMM

$\mathrm{AT}=$ Austria, BE=Belgium, CY=Cyprus, DK=Denmark, EE=Estonia, FI=Finland, FR=France, DE=Germany,

$\mathrm{EL}=$ Greece, IE=Ireland, IT=Italy, LV=Latvia, MT=Malta, NL=Netherlands, N=Norway, PT=Portugal, SI=Slovakia, SK=Slovenia, ES=Spain, $S=$ Sweden, UK=United Kingdom 
Panel C-Quality of the fit

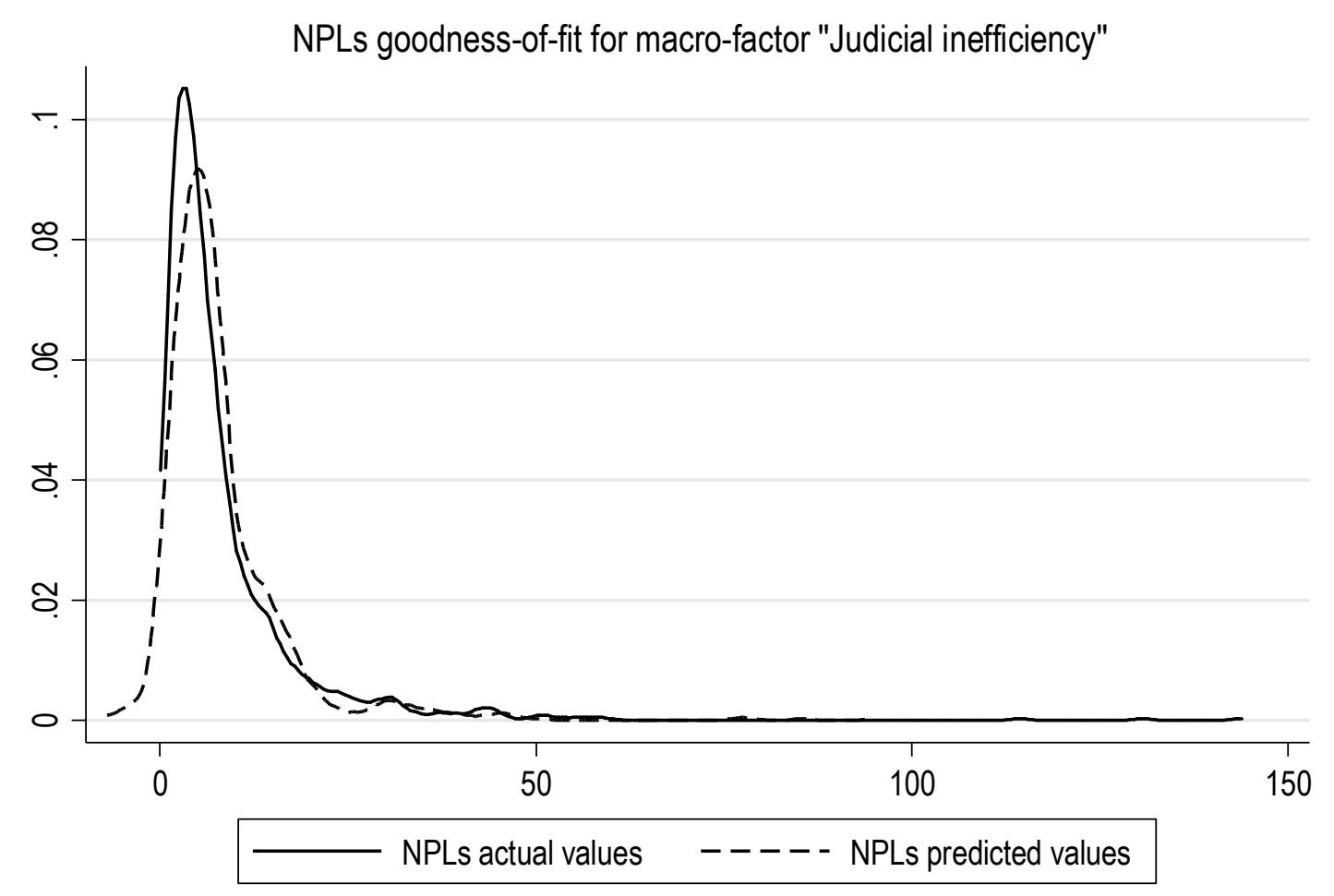

Estimation method: System-GMM 


\section{Table 1-Definition of Variables and Summary Statistics}

This Table shows the definition, the source, and the summary statistics of all the regression variables used to test the effect of judicial inefficiency on the NPLs ratio in Europe. The sample consists of 124 banks under the ECB banking supervision (i.e., single supervisory mechanism banks) and other large European banks located in 21 European countries. The dataset is a balanced panel with 1,191 observations spanning the period from 2006 to 2017.

\begin{tabular}{|c|c|c|c|c|c|c|}
\hline Variable & Definition & Source & $\begin{array}{c}\text { Expected } \\
\text { sign }\end{array}$ & No. & Mean & $\begin{array}{l}\text { Std. } \\
\text { dev. }\end{array}$ \\
\hline \multicolumn{7}{|c|}{ Dependent variable } \\
\hline \multirow[t]{2}{*}{ NPL ratio } & Impaired loans/Gross loans to customers (\%) & Bankscope/ & & 1191 & 8.4 & 10.0 \\
\hline & & BankFocus & & & & \\
\hline \multicolumn{7}{|c|}{ Systematic factors } \\
\hline GDP growth & Real GDP growth $(\%)$ & IMF & - & 1191 & 0.6 & 3.1 \\
\hline Sov. bond yield & 10-years benchmark Government bonds (\%) & Datastream & + & 1191 & 3.2 & 2.6 \\
\hline Judicial inefficie & Time to resolve a dispute (days) & Worldbank & + & 1191 & 595 & 302 \\
\hline \multicolumn{7}{|c|}{ Idiosyncratic factors } \\
\hline \multirow[t]{2}{*}{ Capitalization } & Regulatory Tier 1 Capital/Total assets (\%) & Bankscope/ & $+/-$ & 1191 & 11.7 & 2.9 \\
\hline & & BankFocus & & & & \\
\hline \multirow[t]{2}{*}{ Profitability } & Return on assets (\%) & Bankscope/ & - & 1191 & 0.0 & 1.6 \\
\hline & & BankFocus & & & & \\
\hline \multirow[t]{2}{*}{ Loan Growth } & Loan growth YoY (\%) & Bankscope/ & + & 1191 & 0.0 & 5.3 \\
\hline & & BankFocus & & & & \\
\hline
\end{tabular}




\section{Table 2-Summary Statistics by Country}

This Table contains the summary statistics by country of all the regression variables used to test the effect of judicial inefficiency on the NPLs ratio in Europe during the period 2006-2017.

\begin{tabular}{lcccccccc}
\hline Countries & $\begin{array}{c}\text { N. of } \\
\text { banks }\end{array}$ & $\begin{array}{c}\text { NPL } \\
\text { ratio }\end{array}$ & $\begin{array}{c}\text { GDP } \\
\text { growth }\end{array}$ & $\begin{array}{c}\text { Sov. bond } \\
\text { rate }\end{array}$ & $\begin{array}{c}\text { Jud. } \\
\text { inefficiency }\end{array}$ & Capital. & $\begin{array}{c}\text { Profit. } \\
\text { Loan } \\
\text { growth }\end{array}$ \\
\hline Austria & 6 & 11.3 & 1.4 & 2.5 & 397 & 5.8 & .5 & -.9 \\
Belgium & 4 & 4.6 & 1.2 & 2.8 & 505 & 3.6 & .2 & .7 \\
Cyprus & 4 & 18.7 & .9 & 5.6 & 735 & 5.6 & -.4 & 7.1 \\
Denmark & 4 & 3.2 & .6 & 2.3 & 398.8 & 5.3 & .4 & 6.2 \\
Estonia & 2 & 2.8 & 2.2 & 3.3 & 427.5 & 13.2 & 1.4 & -6.1 \\
Finland & 3 & 3.1 & .7 & 2.4 & 337.5 & 6.3 & .6 & 2.7 \\
France & 10 & 3.6 & 1 & 2.5 & 391.7 & 4.8 & .6 & 5 \\
Germany & 23 & 3.8 & 1.6 & 2.2 & 415.3 & 4.6 & 0 & -.2 \\
Greece & 4 & 23.2 & -1.5 & 9.2 & 1135.6 & 7.3 & -.8 & 5.9 \\
Ireland & 4 & 14.9 & 4.3 & 3.9 & 582.5 & 8.0 & -.7 & -3.5 \\
Italy & 15 & 11.7 & -.2 & 3.7 & 1203.8 & 5.8 & 0 & 4.8 \\
Latvia & 3 & 7.6 & 2.2 & 5.8 & 370.7 & 9.0 & .9 & -2.7 \\
Malta & 2 & 4.8 & 3.3 & 3.3 & 505 & 4.7 & .9 & -1.2 \\
Netherlands & 6 & 3.0 & 1.3 & 2.4 & 514 & 3.9 & .2 & 2.2 \\
Norway & 1 & 1.7 & 1.3 & 2.9 & 300 & 5.9 & .7 & 4.8 \\
Portugal & 4 & 3.6 & .2 & 5.1 & 574.3 & 6.1 & .2 & -1.9 \\
Slovakia & 3 & 5.0 & 3.5 & 3.2 & 602.5 & 7.3 & 1.3 & 11.2 \\
Slovenia & 3 & 20.7 & 1.6 & 3.4 & 1285 & 8.2 & -.6 & 4.5 \\
Spain & 15 & 6.7 & 1.0 & 3.6 & 512.9 & 5.6 & -.4 & .2 \\
Sweden & 4 & 1.0 & 2.0 & 2.3 & 394.5 & 4.2 & .6 & .2 \\
UK. & 4 & 4.4 & 1.3 & 2.9 & 416.5 & 4.3 & .1 & 3.3 \\
\hline
\end{tabular}




\section{Table 3-Correlation Matrix}

This Table shows the correlation among all the regression variables used to test the effect of judicial inefficiency on the NPLs ratio in Europe during the period 2006-2017.

\begin{tabular}{lrrrrrrr}
\hline Variables & $(1)$ & $(2)$ & $(3)$ & $(4)$ & $(5)$ & (6) & (7) \\
\hline (1) NPL ratio & 1.00 & & & & & & \\
(2) GDP growth & -0.09 & 1.00 & & & & & \\
(3) Judicial inefficiency & 0.50 & -0.16 & 1.00 & & & & \\
(4) Sov. bond yield & 0.25 & -0.39 & 0.29 & 1.00 & & & \\
(5) Capitalization & 0.25 & 0.11 & 0.17 & 0.01 & 1.00 & & \\
(6) Profitability & -0.30 & 0.25 & -0.14 & -0.28 & 0.11 & 1.00 & \\
(7) Loan Growth & -0.23 & 0.10 & 0.05 & 0.06 & -0.09 & 0.16 & 1.00 \\
& & & & & & & \\
\hline
\end{tabular}




\section{Table 4-Panel unit root test results}

This Table shows the results of the Levin et al. and the Im et al. panel unit root tests that assume a common unit root process. Moreover, it also shows the results of the Fisher-ADF tests that assume individual unit root processes. All variables are defined in Table 1.

\begin{tabular}{lcccccc}
\hline Variable & $\begin{array}{c}\text { Levin, Lin } \\
\text { and Chu } \boldsymbol{t}\end{array}$ & Prob. & $\begin{array}{c}\text { Im, Pesaran } \\
\text { and Shin W-stat }\end{array}$ & Prob. & $\begin{array}{c}\text { ADF-Fisher } \\
\text { chi-square }\end{array}$ & Prob. \\
\hline NPL ratio & -28.53 & 0.00 & -8.76 & 0.00 & 917.87 & 0.00 \\
GDP growth & -27.51 & 0.00 & -8.05 & 0.00 & 643.08 & 0.00 \\
Sov. bond yield & -19.99 & 0.00 & -4.58 & 0.00 & 317.58 & 0.00 \\
Judicial inefficiency & -22.54 & 0.00 & -6.13 & 0.00 & 456.09 & 0.00 \\
Capitalization & -18.78 & 0.00 & -3.82 & 0.00 & 609.56 & 0.00 \\
Profitability & -14.98 & 0.00 & -4.66 & 0.00 & 491.62 & 0.00 \\
Loan Growth & -34.16 & 0.00 & -10.58 & 0.00 & 871.97 & 0.00 \\
\hline
\end{tabular}


Table 5 - The effect of systematic and idiosyncratic factors on the NPL ratio in Europe

This Table shows the results of two-step system-GMM regressions that examine the effect of judicial inefficiency on the NPLs ratio in Europe. The results for four different models are shown. The dependent variable is the NPL ratio (i.e., total impaired loans over total gross loans to customers). All explanatory variables are as defined in Table 1. Windmeijer standard error corrections are shown between brackets. The signs '*', '**' and '***' denote the $10 \%, 5 \%$ and $1 \%$ significance levels, respectively.

\begin{tabular}{|c|c|c|c|c|}
\hline & Model 1.1 & Model 1.2 & Model 1.3 & Model 1.4 \\
\hline NPL ratio $_{\mathrm{t}-1}$ & $\begin{array}{l}1.0910^{* * *} \\
(0.0488)\end{array}$ & $\begin{array}{l}1.0875^{* * *} \\
(0.0488)\end{array}$ & $\begin{array}{l}1.0821^{* * *} \\
(0.0524)\end{array}$ & $\begin{array}{l}1.0869^{* * *} \\
(0.0524)\end{array}$ \\
\hline NPL ratio ${ }_{t-2}$ & $\begin{array}{c}-0.2159^{* * *} \\
(0.0463)\end{array}$ & $\begin{array}{c}-0.2031^{* * *} \\
(0.0500)\end{array}$ & $\begin{array}{c}-0.1885^{* * *} \\
(0.0519)\end{array}$ & $\begin{array}{c}-0.1842^{* * * *} \\
(0.0534)\end{array}$ \\
\hline \multicolumn{5}{|l|}{ Systematic Factors } \\
\hline 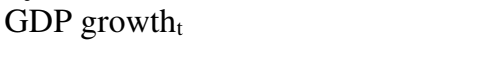 & $\begin{array}{c}-0.0380^{* * * *} \\
(0.0055)\end{array}$ & $\begin{array}{c}-0.0390^{* * *} \\
(0.0059)\end{array}$ & $\begin{array}{c}-0.0406^{* * *} \\
(0.0063)\end{array}$ & $\begin{array}{c}-0.0414^{* * *} \\
(0.0062)\end{array}$ \\
\hline Sov. bond yield ${ }_{t}$ & $\begin{array}{c}0.0437^{* * *} \\
(0.0104)\end{array}$ & $\begin{array}{c}0.0418^{* * *} \\
(0.0106)\end{array}$ & $\begin{array}{c}0.0443^{* * *} \\
(0.0098)\end{array}$ & $\begin{array}{c}0.0429^{* * *} \\
(0.0101)\end{array}$ \\
\hline Judicial inefficiency $y_{t}$ & $\begin{array}{l}0.0002^{* * *} \\
(0.0000)\end{array}$ & $\begin{array}{c}0.0002^{* * * *} \\
(0.0000)\end{array}$ & $\begin{array}{l}0.0001^{* * * *} \\
(0.0000)\end{array}$ & $\begin{array}{c}0.0001^{* * * *} \\
(0.0000)\end{array}$ \\
\hline \multicolumn{5}{|l|}{ Idiosyncratic Factors } \\
\hline Capitalization $_{\mathrm{t}-1}$ & & $\begin{array}{c}-0.0038 \\
(0.0087)\end{array}$ & $\begin{array}{c}-0.0075 \\
(0.0092)\end{array}$ & $\begin{array}{c}-0.0049 \\
(0.0095)\end{array}$ \\
\hline Profitability $\mathrm{t}_{\mathrm{t}-1}$ & & & $\begin{array}{c}0.0156 \\
(0.0147)\end{array}$ & $\begin{array}{c}0.0127 \\
(0.0153)\end{array}$ \\
\hline Loan Growth $_{\mathrm{t}-1}$ & & & & $\begin{array}{c}0.0074^{*} \\
(0.0044)\end{array}$ \\
\hline Constant & $\begin{array}{c}-0.5260^{* * *} \\
(0.0816)\end{array}$ & $\begin{array}{c}-0.4657^{* * *} \\
(0.0949)\end{array}$ & $\begin{array}{c}-0.4173^{* * * *} \\
(0.1040)\end{array}$ & $\begin{array}{c}-0.3895^{* * *} \\
(0.1070)\end{array}$ \\
\hline Observations & 1191 & 1191 & 1191 & 1191 \\
\hline Number of banks & 124 & 124 & 124 & 124 \\
\hline R-squared adj. & 0.93 & 0.93 & 0.93 & 0.93 \\
\hline Number of instruments & 84 & 113 & 142 & 167 \\
\hline Hansen test p-value & 0.12 & 0.31 & 0.81 & 1.00 \\
\hline Arellano-Bond AR(1) test $\mathrm{p}$-value & 0.00 & 0.00 & 0.00 & 0.00 \\
\hline Arellano-Bond $\mathrm{AR}(2)$ test $\mathrm{p}$-value & 0.37 & 0.42 & 0.41 & 0.49 \\
\hline
\end{tabular}




\section{Table 6-Robustness}

This Table presents the results of checks to define the robustness of our results. Panel A tests the role of size, specialization, and systemic importance. Panel B uses different systematic and idiosyncratic factors and different estimation techniques. The dependent variable is the NPL ratio (i.e., total impaired loans over total gross loans to customers). All explanatory variables are as defined in Table 1 . Windmeijer standard error corrections are shown between brackets. The signs ' $*$ ', '**' and ' $* * *$ ' denote the $10 \%, 5 \%$, and $1 \%$ significance levels, respectively.

Panel A

\begin{tabular}{|c|c|c|c|}
\hline & $\begin{array}{c}\text { Model } 2.1 \\
\text { GMM }\end{array}$ & $\begin{array}{c}\text { Model } 2.2 \\
\text { GMM }\end{array}$ & $\begin{array}{c}\text { Model } 2.3 \\
\text { GMM }\end{array}$ \\
\hline NPL ratiot-1 & $\begin{array}{c}1.0843^{* * *} \\
(0.0536)\end{array}$ & $\begin{array}{c}1.0881^{* * *} \\
(0.0513)\end{array}$ & $\begin{array}{c}1.0863^{* * *} \\
(0.0518)\end{array}$ \\
\hline NPL ratio $_{t-2}$ & $\begin{array}{c}-0.1842^{* * * *} \\
(0.0539)\end{array}$ & $\begin{array}{c}-0.1824^{* * * *} \\
(0.0523)\end{array}$ & $\begin{array}{c}-0.1841^{\text {**** }} \\
(0.0523) \\
\end{array}$ \\
\hline \multicolumn{4}{|l|}{ Systematic Factors } \\
\hline GDP growth $_{t}$ & $\begin{array}{c}-0.0413^{* * *} \\
(0.0058)\end{array}$ & $\begin{array}{c}-0.0413^{* * *} \\
(0.0060)\end{array}$ & $\begin{array}{c}-0.0414^{* * *} \\
(0.0060)\end{array}$ \\
\hline Sov. bond yield ${ }_{t}$ & $\begin{array}{c}0.0438^{* * * *} \\
(0.0102)\end{array}$ & $\begin{array}{c}0.0445^{* * *} \\
(0.0104)\end{array}$ & $\begin{array}{c}0.0433^{* * * *} \\
(0.0098)\end{array}$ \\
\hline Judicial inefficiency $_{t}$ & $\begin{array}{c}0.0001^{* * * *} \\
(0.0000)\end{array}$ & $\begin{array}{c}0.0001^{* * * *} \\
(0.0000)\end{array}$ & $\begin{array}{c}0.0001^{* * * *} \\
(0.0000)\end{array}$ \\
\hline \multicolumn{4}{|l|}{ Idiosyncratic Factors } \\
\hline Capitalization $_{\mathrm{t}-1}$ & $\begin{array}{c}-0.0050 \\
(0.0113)\end{array}$ & $\begin{array}{c}-0.0061 \\
(0.0102)\end{array}$ & $\begin{array}{c}-0.0063 \\
(0.0104)\end{array}$ \\
\hline Profitability $_{\mathrm{t}-1}$ & $\begin{array}{c}0.0138 \\
(0.0158)\end{array}$ & $\begin{array}{c}0.0127 \\
(0.0152)\end{array}$ & $\begin{array}{c}0.0124 \\
(0.0156)\end{array}$ \\
\hline Loan Growth t-1 $_{1}$ & $\begin{array}{c}0.0062 \\
(0.0042) \\
\end{array}$ & $\begin{array}{l}0.0072^{*} \\
(0.0043)\end{array}$ & $\begin{array}{c}0.0069 \\
(0.0045) \\
\end{array}$ \\
\hline \multicolumn{4}{|l|}{ Dummies } \\
\hline Dummy Large Bank & $\begin{array}{c}0.0323 \\
(0.0780)\end{array}$ & & \\
\hline Dummy Medium Bank & $\begin{array}{c}0.0729 \\
(0.0713)\end{array}$ & & \\
\hline Dummy Commercial Bank & & $\begin{array}{c}0.0782 \\
(0.0685)\end{array}$ & \\
\hline Dummy Investment Bank & & $\begin{array}{c}0.0610 \\
(0.0797)\end{array}$ & \\
\hline Dummy SIFI & & & $\begin{array}{l}-0.0175 \\
(0.0277)\end{array}$ \\
\hline Constant & $\begin{array}{c}-0.4384^{* * *} \\
(0.1606)\end{array}$ & $\begin{array}{c}-0.4349^{* * * *} \\
(0.1533)\end{array}$ & $\begin{array}{c}-0.3814^{* * *} \\
(0.1163) \\
\end{array}$ \\
\hline Observations & 1191 & 1191 & 1191 \\
\hline Number of banks & 124 & 124 & 124 \\
\hline R-squared adj. & 0.93 & 0.93 & 0.93 \\
\hline Number of instruments & 169 & 169 & 168 \\
\hline Hansen test p-value & 1.00 & 1.00 & 1.00 \\
\hline Arellano-Bond AR(1) test p-value & 0.00 & 0.00 & 0.00 \\
\hline Arellano-Bond AR(2) test $\mathrm{p}$-value & 0.50 & 0.49 & 0.51 \\
\hline
\end{tabular}


Panel B

\begin{tabular}{|c|c|c|c|c|c|}
\hline & $\begin{array}{c}\text { Model } 2.4 \\
\text { GMM }\end{array}$ & $\begin{array}{c}\text { Model } 2.5 \\
\text { GMM }\end{array}$ & $\begin{array}{c}\text { Model } 2.6 \\
\text { GMM }\end{array}$ & $\begin{array}{c}\text { Model } 2.7 \\
\text { GMM }\end{array}$ & $\begin{array}{c}\text { Model } 2.8 \\
\text { OLS }\end{array}$ \\
\hline NPL Ratio $_{\mathrm{t}-1}$ & $\begin{array}{l}1.0760^{* * * *} \\
(0.0544)\end{array}$ & $\begin{array}{l}1.0788^{* * * *} \\
(0.0493)\end{array}$ & $\begin{array}{l}1.0504^{* * *} \\
(0.0508)\end{array}$ & $\begin{array}{l}1.1064^{* * * *} \\
(0.0475)\end{array}$ & $\begin{array}{c}0.9190^{* * * *} \\
(0.1307)\end{array}$ \\
\hline NPL Ratiot 2 & $\begin{array}{c}-0.1764^{* * *} \\
(0.0543)\end{array}$ & $\begin{array}{c}-0.1778^{* * *} \\
(0.0539)\end{array}$ & $\begin{array}{c}-0.1565^{* * *} \\
(0.0513)\end{array}$ & $\begin{array}{c}-0.2384^{* * *} \\
(0.0444)\end{array}$ & $\begin{array}{c}-0.0572 \\
(0.1440)\end{array}$ \\
\hline \multicolumn{6}{|l|}{ Systematic Factors } \\
\hline Real GDP growth & $\begin{array}{c}-0.0394^{* * *} \\
(0.0065)\end{array}$ & $\begin{array}{c}-0.0410^{* * * *} \\
(0.0068)\end{array}$ & & $\begin{array}{c}-0.0395^{* * * *} \\
(0.0061)\end{array}$ & $\begin{array}{c}-0.3437^{* * *} \\
(0.0580)\end{array}$ \\
\hline Sov. bond yield $t$ & $\begin{array}{l}0.0422^{* * * *} \\
(0.0101)\end{array}$ & $\begin{array}{l}0.0425^{\text {**** }} \\
(0.0111)\end{array}$ & $\begin{array}{c}0.0395^{* * *} \\
(0.0088)\end{array}$ & $\begin{array}{l}0.0386^{* * * *} \\
(0.0105)\end{array}$ & $\begin{array}{c}0.2995^{\text {*** }} \\
(0.0680)\end{array}$ \\
\hline Judicial inefficiency $\mathrm{t}_{\mathrm{t}}$ & $\begin{array}{c}0.0002^{* * * *} \\
(0.0000)\end{array}$ & $\begin{array}{c}0.0001^{* * * *} \\
(0.0000)\end{array}$ & $\begin{array}{l}0.0001^{* * * *} \\
(0.0000)\end{array}$ & $\begin{array}{l}0.0002^{* * * *} \\
(0.0001)\end{array}$ & $\begin{array}{c}0.0048^{* * * *} \\
(0.0018)\end{array}$ \\
\hline \multicolumn{6}{|l|}{ Idiosyncratic Factors } \\
\hline Equity to Total Assetst-1 & $\begin{array}{c}-0.0133 \\
(0.0092)\end{array}$ & & & & \\
\hline Profitability $_{\mathrm{t}-1}$ & $\begin{array}{c}0.0138 \\
(0.0158)\end{array}$ & & $\begin{array}{c}0.0087 \\
(0.0142)\end{array}$ & & $\begin{array}{c}0.0000 \\
(0.0009)\end{array}$ \\
\hline Loan Growth ${ }_{t-1}$ & $\begin{array}{l}0.0072^{* *} \\
(0.0033)\end{array}$ & $\begin{array}{c}0.0082^{*} \\
(0.0043)\end{array}$ & $\begin{array}{c}0.0072^{*} \\
(0.0042)\end{array}$ & & $\begin{array}{c}0.0298 \\
(0.0292)\end{array}$ \\
\hline Capitalization $_{\mathrm{t}-1}$ & & $\begin{array}{c}-0.0042 \\
(0.0099)\end{array}$ & $\begin{array}{c}-0.0042 \\
(0.0111)\end{array}$ & & $\begin{array}{c}0.0013 \\
(0.0905)\end{array}$ \\
\hline $\mathrm{ROE}_{\mathrm{t}-1}$ & & $\begin{array}{c}0.0005 \\
(0.0012) \\
\end{array}$ & & & \\
\hline \multicolumn{6}{|l|}{ Oth. Systematic Factors } \\
\hline GDP Growth Weighted $_{t}$ & & & $\begin{array}{c}-0.0448^{* * *} \\
(0.0057)\end{array}$ & & \\
\hline Unemployment rate $_{\mathrm{t}}$ & & & & $\begin{array}{c}0.0004 \\
(0.0030)\end{array}$ & \\
\hline Constant & $\begin{array}{c}-0.3635^{* * *} \\
(0.1090)\end{array}$ & $\begin{array}{c}-0.3954^{* * *} \\
(0.1297)\end{array}$ & $\begin{array}{c}-0.4007^{* * *} \\
(0.1237)\end{array}$ & $\begin{array}{c}-0.5493^{* * * *} \\
(0.1285)\end{array}$ & \\
\hline Observations & 1191 & 1191 & 1191 & 1191 & 1191 \\
\hline Number of banks & 124 & 124 & 124 & 124 & 124 \\
\hline Bank fixed effects & no & no & no & no & yes \\
\hline R-squared adj. & 0.93 & 0.93 & 0.93 & 0.93 & 0.73 \\
\hline Number of instruments & 167 & 167 & 145 & 113 & \\
\hline Hansen test $\mathrm{p}$-value & 0.99 & 0.99 & 0.83 & 0.27 & \\
\hline Arellano-Bond AR(1) test $\mathrm{p}$-value & 0.00 & 0.00 & 0.00 & 0.00 & \\
\hline Arellano-Bond AR(2) test $\mathrm{p}$-value & 0.47 & 0.60 & 0.95 & 0.31 & \\
\hline
\end{tabular}




\section{Appendix}

In this appendix we test if judicial inefficiency has a diverse impact on different types of loans (Louzis et al., 2012). As data are not available to analyze this aspect from 2007 to 2018 for a large panel of European banks, we need to merge our dataset with the information provided in the EUwide transparency exercise by the European Banking Authority (EBA). Doing so, we have data from 2014 to 2018 for 68 banks, and we can calculate two different dependent variables: nonfinancial firm NPL ratio and household NPL ratio. Due to the shorter period and a lower number of banks, we employ an OLS regression to re-estimate Equation 1 as follows:

$N P L$ ratio $_{\mathrm{i}, \mathrm{c}, \mathrm{t}}=\alpha_{0}+\beta_{1}$ GDP growth $_{c, t}+\beta_{2}$ Sov. bond yield S,$t+\beta_{3}$ Judicial inefficiency ${ }_{c, t}$

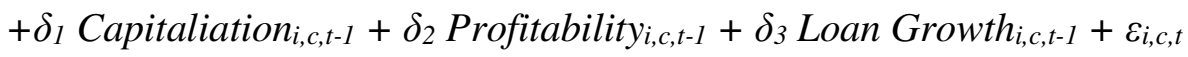

where NPL ratio $_{\mathrm{i}, \mathrm{c}, \mathrm{t}}$ denotes, alternately, non-financial firm NPL ratio (model A1.1) or household NPL ratio (model A1.2). As can be seen in Table A1 (column one and two), judicial inefficiency is still highly significant with the expected sign in both models. GDP growth and sovereign bond yield are also significant, confirming our main results. Concerning bank-specific variables, in this specification, none of the three variables employed is significant.

We can also test the significance of judicial inefficiency considering just domestic NPLs. In this way, we can have a better identification between our proxy of judicial inefficiency, calculated at country level, and the NPLs calculated just on domestic loans. For this test, we need to merge our dataset with the information provided in the EU-stress-test exercise by EBA. In this case, we have data for 2014, 2016 and 2018 for 66 banks, and we can calculate two different dependent variables: 
corporate NPL ratio and retail NPL ratio. For the same reasons explained before, we employ an OLS regression to estimate Equation A1. The only difference with Equation A1 is that now NPL ratio $_{\mathrm{i}, \mathrm{c}, \mathrm{t}}$ denotes, alternately, domestic corporate loans (model A1.3) or domestic retail loans (model A1.4). As can be seen in Table A1 (column third and four), judicial inefficiency is still highly significant. In this specification sovereign bond yield is significant, while GDP growth is not. In these estimates, as before, none of the bank-specific variables is significant.

\section{Table A1 -The effect of systematic and idiosyncratic factors on the NPL ratio in Europe}

This Table shows the results of OLS regressions that examine the effect of judicial inefficiency on the NPL ratio in Europe. The results for four different models are shown. All explanatory variables are as defined in Table 1. Robust standard errors are shown between brackets. The signs ' $*$ ', '**' and '***' denote the $10 \%, 5 \%$ and $1 \%$ significance levels, respectively.

\begin{tabular}{|c|c|c|c|c|}
\hline & $\begin{array}{c}\text { Model A1.1 } \\
\text { (non-financial } \\
\text { firm NPL ratio) }\end{array}$ & $\begin{array}{l}\text { Model A1.2 } \\
\text { (household } \\
\text { NPL ratio) }\end{array}$ & $\begin{array}{l}\text { Model A1.3 } \\
\text { (domestic } \\
\text { corporate } \\
\text { NPL ratio) } \\
\end{array}$ & $\begin{array}{c}\text { Model A1.4 } \\
\text { (domestic } \\
\text { retail } \\
\text { NPL ratio } \\
\end{array}$ \\
\hline \multicolumn{5}{|l|}{ Systematic Factors } \\
\hline 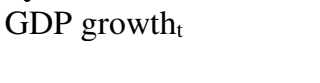 & $\begin{array}{c}-0.1383^{* * * *} \\
(0.0452)\end{array}$ & $\begin{array}{c}-0.1328^{* * *} \\
(0.0440)\end{array}$ & $\begin{array}{c}0.0739 \\
(0.0737)\end{array}$ & $\begin{array}{c}0.0305 \\
(0.0803)\end{array}$ \\
\hline Benchmark Bonds $\mathrm{t}_{\mathrm{t}}$ & $\begin{array}{c}0.1560^{*} \\
(0.0896)\end{array}$ & $\begin{array}{c}0.2647^{* * * *} \\
(0.0793)\end{array}$ & $\begin{array}{c}0.2486^{* * * *} \\
(0.0789)\end{array}$ & $\begin{array}{l}0.2545^{* * *} \\
(0.0710)\end{array}$ \\
\hline Days $s_{t}$ & $\begin{array}{c}0.0012^{* * * *} \\
(0.0003)\end{array}$ & $\begin{array}{c}0.0011^{* * * *} \\
(0.0003)\end{array}$ & $\begin{array}{c}0.0022^{* * *} \\
(0.0004)\end{array}$ & $\begin{array}{c}0.0023^{* * *} \\
(0.0004)\end{array}$ \\
\hline \multicolumn{5}{|l|}{ Idiosyncratic Factors } \\
\hline Reg. Capital ${ }_{t-1}$ & $\begin{array}{c}0.0859 \\
(0.0643)\end{array}$ & $\begin{array}{c}0.0808 \\
(0.0524)\end{array}$ & $\begin{array}{c}-0.0179 \\
(0.0628)\end{array}$ & $\begin{array}{c}0.0302 \\
(0.0529)\end{array}$ \\
\hline Profitability $_{\mathrm{t}-1}$ & $\begin{array}{c}-0.1640 \\
(0.1275)\end{array}$ & $\begin{array}{c}-0.1180 \\
(0.1145)\end{array}$ & $\begin{array}{c}-0.0629 \\
(0.0681)\end{array}$ & $\begin{array}{c}0.0110 \\
(0.0480)\end{array}$ \\
\hline Loan Growth ${ }_{t-1}$ & $\begin{array}{c}-0.0067 \\
(0.0106)\end{array}$ & $\begin{array}{l}-0.0001 \\
(0.0119)\end{array}$ & $\begin{array}{l}-0.0368 \\
(0.0225)\end{array}$ & $\begin{array}{l}-0.0138 \\
(0.0260)\end{array}$ \\
\hline Constant & $\begin{array}{c}-3.9807^{* * * *} \\
(0.3178)\end{array}$ & $\begin{array}{c}-4.7409^{* * *} \\
(0.2715)\end{array}$ & $\begin{array}{c}-4.6679^{* * *} \\
(0.5310)\end{array}$ & $\begin{array}{c}-5.6246^{* * *} \\
(0.4632)\end{array}$ \\
\hline $\begin{array}{l}\text { Obs. } \\
\text { Adj.R2 }\end{array}$ & $\begin{array}{l}311 \\
0.48\end{array}$ & $\begin{array}{c}311 \\
0.57\end{array}$ & $\begin{array}{c}148 \\
0.38\end{array}$ & $\begin{array}{c}145 \\
0.48\end{array}$ \\
\hline
\end{tabular}

